\title{
IMPLEMENTASI ALGORITMA JARO-WINKLER DAN LEVENSTEIN DISTANCE DALAM PENCARIAN DATA PADA DATABASE
}

\author{
Yulianingsih \\ Program Studi Informatika, Universitas Indraprasta PGRI \\ Jl. Nangka No.58,Tanjung Barat, Jakarta Selatan \\ E-Mail: yuliagniya@yahoo.co.id
}

\begin{abstract}
Abstrak
Data adalah sumber informasi yang harus bernilai atau mengandung makna benar yang dapat digunakan atau diolah hingga memberikan manfaat bagi setiap orang yang membutuhkan. Data dapat ditemukan atau dicari sesuai degan kebutuhan dengan demikian diperlukan pemahaman yang baik mengenai beberapa metode pencarian untuk mendapatkan hasil yang tepat. Dalam penulisan disampaikan hasil dari pengujian komparasi menggunakan algortima Levenshtein Distance dan Jero-Winkler terhadap sejumlah data-data nama yang memiliki tingkat kemiripan yang tinggi. Tujuan dari penelitian ini adalah menentukan satu dari dua metode yang memiliki tingkat validasi tertinggi dalam pencarian data yang memiliki kesamaan tinggi. Pengujian dilakukan secara berulang dan kemudian dilakukan observasi pada tiap tahapan. Temuan hasil dapat digunakan sebagai dasar penentuan penggunaan metode yang tepat dalam pencarian data.
\end{abstract}

Kata Kunci: Data, Levenshtein Distance, Jaro-Winkler, Kemiripan

\begin{abstract}
Data is a source of information that must be valued of contains true meaning which can be used or processed to benefit everyone need. Data can be found or searched in accordance with the needs thus required a good understanding of some search methods to get the right results. In this writing submitted the results of comparative testing using Levenshtein Distance and Jero-Winkler algorithm against a number of human name data which has a high degree of similarity. The purpose of this study is to determine one of two methods that have highest level of validation in search data that has a high similarity.Testing is done repeatedly and then carried out observations at each stage. Finding can be used as a basic for determining the appropriate method of use in data search.
\end{abstract}

Key Words: Data, Levenshtein Distance, Jaro-Winkler,Similarity

\section{Pendahuluan}

Data dalam sebuah informasi merupakan sumber pertama yang apabila dikembangkan akan menghasilkan suatu nilai yang bermanfaat bagi orang lain. Saat seorang membutuhkan data dipastikan data tersebut haruslah bernilai benar, dalam pengertian sesuai dengan kebutuhan. Dengan demikian proses pencarian data haruslah sesuai dengan syarat yang dicari. Dan untuk memperoleh kondisi tersebut maka diperlukan pemahaman yang baik mengenai beberapa metode algoritma pencarian.

Diasumsikan bagaimana mengidentifikasi apakah data pelanggan tersebut merupakan pelanggan yang sama dari sekian banyak data pelanggan yang ada. Daftar pelanggan memiliki duplikasi dikarenakan adanya kesalahan ejaan atau kesalahan ketik ketika proses memasukan data. Dengan kata lain pelanggan tersebut seharusnya merupakan pelanggan yang sama. Melalui tulisan ini dilakukan pegujian dan pembuktian bagaimana metode algoritma Levenshtein Distance dan Jaro-Winkler dapat meberikan solusi terhadapat permasalah tersebut. Dengan parameter nama dan tangal lahir yang sama kedua algoritma 
digunakan untuk mengukur kesamaan yang dimiliki antara dua string data dan menentukan nilai perkiraan kemiripan data. Dalam penelitian juga ditentukan waktu terbaik yang dimiliki dari kedua algoritma. Diharapkan hasil dari penelitian dapat digunakan sebagai acuan penelitian mengenai algoritma pencarian similarity untuk berbagai kebutuhan lainnya.

\section{Tinjauan Pustaka}

\section{Query Database}

Query adalah penyelidikan ke database menggunakan pernyataan SELECT. Query digunakan untuk mengekstrak data dari database dalam format yang dapat dibaca sesuai permintaan pengguna. Misalnya, bagaimana mencari data pelanggan pada sebuah tabel yang mempunyai kriteria tertentu. Query ke database untuk informasi pelanggan yang dapat digunakan adalah Query khas yang dapat dilakukan dalam database.

SELECT *, levenshtein('nama`, "Thomas") + levenshtein('tgl_lahir`, "1965-05-08") AS score FROM warga ORDER BY score ASC LIMIT 10;

Kalimat diatas merupakan query database dengan parameter pencarian berdasarkan nama mengandung kata "Thomas" dan tanggal lahir "1965-05-08" pada tabel warga dengan mengurutkan hasil pencarian secara ascending dan ditampilkan persepuluh baris.

\section{Matrik String}

Matrik string adalah matrik yang digunakan untuk mengukur jarak antara dua string teks untuk mendekati kemiripan atau perbandingan dan pencarian. Beberapa algoritma yang menggunakan konsep dasar matrik string antara lain Levenshtein distance dan Jero-Winkler.

Dalam beberapa bidang ilmu algoritma Levenshtein Distance dan Jaro-Winkler seringkali digunakan untuk proses analisis suatu keadaan antara lain penggunaan dalam deteksi kecurangan, pencocokan RNA atau DNA, idetifikasi plagiarisme, database atau data mining, analisis fingerprint, image dan sebagainya.

\section{Algoritma Levenshtein Distance}

Levenshtein Distance atau Edit Distance merupakan metrik string untuk mengukur perbedaan antara dua urutan. Pada algoritma Levenshtein Distance semakin kecil nilai skor yang dimiliki maka kemiripan yang dimiliki semakin tinggi.

Dengan rumus

$$
\begin{aligned}
\operatorname{lev}_{a, b}(i, j)=\quad \max (i, j) & \\
& \operatorname{lev}_{a, b}(i-1, j)+1 \\
\min \quad & \operatorname{lev}_{a, b}(i, j-1)+1 \\
& \operatorname{lev}_{a, b}(i-1, j-1)+1\left(a_{i} \neq b j\right)
\end{aligned}
$$

Dimana

$1\left(a_{\mathrm{i}} \neq \mathrm{bj}\right) \quad=$ fungsi indikator

$\operatorname{lev}_{\mathrm{a}, \mathrm{b}}(\mathrm{i}, \mathrm{j}) \quad=$ jarak pertama karakter dari a dan karakter pertama dari $\mathrm{b}$

\section{Algoritma Jaro-Winkler}

Jaro-Winkler merupakan varian dari metrik Jaro Distance biasanya digunakan dibidang keterkaitan rekaman (duplikat) dirancang dan paling sesuai untuk string pendek. Pada JaroWinkler untuk dua string semakin tinggi jarak, semakin mirip data yang diperoleh dengan skor 0 sama dengan tidak ada persamaan dan 1 sama persis. Dasar dari algoritma ini 
memiliki kriteria antara lain menghitung panjang string, menemukan jumlah karakter yang sama di dalam dua string dan nenemukan jumlah transposisi.

Rumus yang digunakan:

$\mathrm{d}_{\mathrm{j}}=\frac{1}{3} \mathrm{x}\left(\frac{m}{s 1}+\frac{m}{s 2}+\frac{m-t}{s}\right)$

Dimana

$\mathrm{m} \quad=$ jumlah karakter yang sama persis

$\mathrm{s}_{1} \quad$ = pangjang string 1

$\mathrm{s}_{2} \quad=$ pangjang string 2

$\mathrm{t}=$ jumlah transposisi (karakter yang sama pada string)

Dan jarak yang dapat dibenarkan adalah jika tidak melebihi

$\left(\max \frac{s 1, s 2}{s}\right) \leftarrow 1$

Bila string $\mathrm{s}_{1}$ dan $\mathrm{s}_{2}$ yang diperbandingkan maka Jaro-Winkler distancenya $\left(\mathrm{d}_{\mathrm{w}}\right)$ adalah:

$\mathrm{dw}=\mathrm{dj}+(l \mathrm{p}(1-\mathrm{dj}))$

dimana:

$\mathrm{dj} \quad=$ Jaro distance untuk strings s1 dan s2

$l \quad=$ panjang prefiks umum di awal string nilai maksimalnya 4 karakter (panjang karakter yg sama sebelum ditemukan ketidaksamaan max 4)

$\mathrm{p} \quad=$ konstanta scaling factor. Nilai standar untuk konstanta ini menurut Winkler adalah $\mathrm{p} \quad 0,1$.

\section{Penelitian lain yang relevan}

Menururt Dwitiyastuti dkk (2013) pada sistem pengoreksi ejaan untuk mengatasi terjadinya kesalahan ejaan algoritma Levenshtein Distance dapat diterapkan dengan baik. Pengujian sistem terhadap pencarian kata dalam kamus dilakukan dengan cara memasukkan 14 kata berbeda dengan kemungkinan kata tersebut ejaannya benar atau salah. Parameter keberhasilan pada sistem adalah kesesuaian antara keberadaan kata dalam kamus dengan tampilan kata yang salah pada system.

Menurut Kurniawati (2010) bahwa Algoritma Jero-Winkler dapat diterapkan dengan baik dalam sebuah aplikasi melakukan untuk pendeteksian plagiarisme pada sebuah karya ilmiah berbahasa Indonesia. Pendeteksian dengan urutan kata yang sama aplikasi berhasil menemukan adanya plagiarisme namun ketika urutan kata dibedakan aplikasi tidak mendapati adanya plagiarisme pada sebuah karya ilmiah.

Menurut Oktamal, F dkk(2015)bahwa Implementasi Jaro-Winkler dalam aplikasi mampu mendeteksi hama dan penyakit pada tanaman padi. Dalam penelitian dilakukan kombinasi metode Steaming untuk menyederhanakan inputan kemudian jika inputan tidak sesuai maka inout akan diperbaiki dengan metode Jaro-Winkler selanjutnya diidentifikasi dengan menggunakan Hamming Distance.

Dita, R.P. (2015) mengatakan bahwa metode approximate string matching menggunakan algoritma levenshtein distance mampu menghitung jarak minimum pengubahan suatu string menjadi string lain dengan optimal. Penelitian juga membahas analisis hasil penerapan algoritma levenshtein distance untuk search suggestion pada aplikasi D-TAB. 


\section{Metodologi Penelitian}

Data yang digunakan dalam oberservasi adalah 100.000 record data menggunakan database MySql (field name, tanggal lahir, tempat lahir, no KTP, alamat) dengan parameter pencarian nama dan tgl_lahir. Sumber data pengujian didapat dari sample Data Spawner Generator.

Tahapan eksperimen dalam penelitian dilakukan untuk mencari pengaruh perlakuan tertentu terhadap yang lain dalam kondisi yang terkendalikan.

Langkah-langkah penelitian yang digunakan untuk mendapatkan hasil diuraikan berdasarkan urutan proses yang ditunjukan pada gambar 1 .

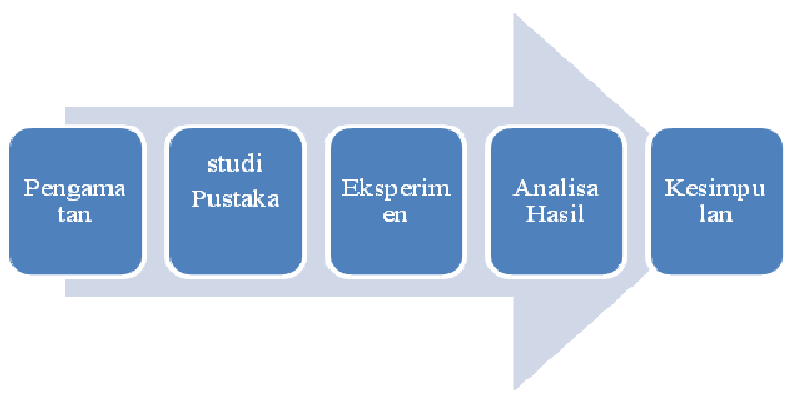

\section{Gambar 1. Langkah-langkah Penelitian}

Penelitian dibagi kedalam 5 langkah kegiatan, yaitu: Pengamatan, studi Pustaka, Eksperimen, Analisa Hasil dan Kesimpulan. Berikut uraian dari setiap langkah penelitian.

Langkah ke-1 Pengamatan, merupakan kegiatan yang dilakukan diawal penelitian untuk mendapatkan permasalahan yang dianggap perlu untuk diberikan solusi yang tepat. Berdasarkan pengamatan ditemukan bagaimana metode pencarian data yang tepat yang dapat memberikan hasil terbaik ketika melakukan proses pencarian data tertentu pada suatu kelompok data. Ditentukan dua metode algoritma yang diduga dapat memberikan solusi yaitu metode Levenshtein Distance dan metode Jaro-Winkler.

Langkah ke-2 Studi Pustaka, mencari beberapa kemungkinan solusi ilmiah melalui literatur terpercaya dari sejumlah buku, jurnal dan situs yang dianggap mampu memberikan jawaban yang paling tepat. Selanjutnya melakukan penyusunan query database. Query pertama memanggil stored procedure yang mengandung algoritma Levenshtein Distance. Query kedua memanggil stored procedure yang mengandung algoritma Jaro-Winkler.

Langkah 3 Eksperimen

Query pertama algoritma Levenshtein Distance dijalankan pada database kemudian dilakukan pencacatan hasil. Demikian selanjutnya dilakukan perulangan sebanyak lima kali dengan metode yang sama.

Query kedua algoritma Jaro-Winkler dijalankan pada database kemudian dilakukan pencacatan hasil. Demikian selanjutnya dilakukan perulangan sebanyak lima kali dengan metode yang sama. Kedua cara diberlakukan dengan cara yang sama pada kumpulan data yang sama tujuannya untuk mendapatkan kesamaan perlakuan kemudian dilakukan pencatatan dari setiap hasil akhir.

Langkah ke-4 Analisa Hasil, dari beberapa kali pengujian menggunakan dua metode tersebut ditentukan apakah kedua metode memperoleh hasil sesuai dengan yang diharapkan. Selanjutnya dilakukan perbandingan hasil dari kedua metode tersebut. 
Langkah ke-5 Kesimpulan, dari sejumlah eksperimen terhadap kedua metode dimbil kesimpulan bahwa metode yang menghasilkan persentasi tertinggi adalah metode terbaik yang mendekati kemiripan dengan nilai parameter dengan waktu pencarian yang optimal.

\section{Hasil dan Pembahasan}

\section{Pengujian dengan Algoritma Levenshtein Distance}

Menyusun kode algoritma Stored Procedure sebagai berikut

BEGIN

DECLARE s1_len, s2_len, i, j, c, c_temp, cost INT;

DECLARE s1_char CHAR;

DECLARE cv0, cv1 VARBINARY(256);

SET s1_len $=$ CHAR_LENGTH(s1), s2_len $=$ CHAR_LENGTH(s2), cv1 = ' $\square$ ', j = 1, i = 1, c $=0$;

IF $\mathrm{s} 1=\mathrm{s} 2 \mathrm{THEN}$

RETURN 0;

ELSEIF s1_len $=0$ THEN

RETURN s2_len;

ELSEIF s2_len $=0$ THEN

RETURN s1_len;

ELSE

WHILE $\mathrm{j}<=$ s2_len DO

SET $\mathrm{cv} 1=\operatorname{CONCAT}(\mathrm{cv} 1, \operatorname{UNHEX}(\operatorname{HEX}(\mathrm{j}))), \mathrm{j}=\mathrm{j}+1$;

END WHILE;

WHILE i $<=$ s1_len DO

SET s1_char $=$ SUBSTRING $(s 1, i, 1), c=i, c v 0=\operatorname{UNHEX}(\operatorname{HEX}(i)), j=1$;

WHILE $\mathrm{j}<=$ s2_len DO

SET $\mathrm{c}=\mathrm{c}+1$

IF $s 1 \_c h a r=$ SUBSTRING( $\left.\mathrm{s} 2, \mathrm{j}, 1\right)$ THEN SET cost $=0$; ELSE SET cost = 1; END IF;

SET c_temp $=$ CONV $(\operatorname{HEX}(\operatorname{SUBSTRING}(\mathrm{cv} 1, \mathrm{j}, 1)), 16,10)+$ cost;

IF c > c_temp THEN SET c = c_temp; END IF;

SET c_temp $=\operatorname{CONV}(\operatorname{HEX}(\operatorname{SUBSTRING}(\mathrm{cv} 1, \mathrm{j}+1,1)), 16,10)+1$;

IF c > c_temp THEN SET c = c_temp; END IF;

SET cv0 $=$ CONCAT $(\mathrm{cv} 0, \operatorname{UNHEX}(\operatorname{HEX}(\mathrm{c}))), \mathrm{j}=\mathrm{j}+1$;

END WHILE;

SET $\mathrm{cv} 1=\mathrm{cv} 0, \mathrm{i}=\mathrm{i}+1$;

END WHILE;

END IF;

RETURN c;

END

Kemudian dilakukan pemanggilan Stored Procedure dengan Algoritma Levenshtein

Distance Dalam Query SELECT *, levenshtein('nama', "Thomas") + levenshtein('tgl_lahir', "1965-05-08") AS score FROM warga ORDER BY score ASC LIMIT 10;

\section{Hasil Query Dengan Algoritma Levenshtein Distance}

Pada Tabel 1ditampilkan hasil query dengan parameter nama yang mengandung kata Thomas dan tgl_lahir pada 1965-05-08 dan ditampilkan dalam setiap sepuluh baris record. 
Tabel 1. Hasil Query Levenshtein Distance

\begin{tabular}{lllllll}
\hline id & nama & tgl_lahir & tpt_lahir & no-ktp & alamat & skore \\
\hline 80938 & Thomas York & $1965-05-08$ & Fresno & $660-61-5290$ & $\begin{array}{l}\text { 15025 North Holy See (Vatican } \\
\text { City State) Ave. }\end{array}$ & 7 \\
& & & & & \\
25470 & Kato Roman & $1965-08-08$ & Marquette & $154-70-4907$ & 31666 East Guyana Ct. & 9 \\
33854 & Ava Mays & $1961-05-09$ & St. George & $902-56-8003$ & 28970 Gardena Ln. & 9 \\
88430 & Seth Mays & $1996-09-09$ & Minnetonka & $161-53-4121$ & 48947 East Oman Ave. & 9 \\
23404 & Laith Dale & $1965-05-06$ & San Rafael & $777-85-4453$ & 35123 North Turkey Ave & 10 \\
36623 & Uta Hogan & $2015-05-03$ & Niaga Falls & $395-67-3695$ & 48758 South Bell Way & 10 \\
44278 & Oren Melton & $1965-05-08$ & Vincennes & $641-08-6153$ & 50234 North Virgin Islands, British & 10 \\
& & & & Way & 10 \\
65359 & Suki Thomas & $1971-09-08$ & Seattle & $548-63-3467$ & 22346 West American Samoa Way & 10 \\
67617 & Thomas Holt & $1963-05-08$ & Hollister & $628-27-0989$ & 59106 South Monrovia Blvd. & 10 \\
\hline 81741 & Lara Thomas & $1955-02-02$ & Pasco & $095-02-5895$ & 45442 West Gambia Ave. & 10 \\
\hline
\end{tabular}

Berdasarkan tabel 1 ditemukan bahwa urutan nama teratas terdiri dari nama yang mengandung "Thomas" dan kombinasi kata "Thomas" pada urutan selanjutnya, pada pengujian algoritma Levenshtein Distance semakin kecil nilai skor yang dihasilkan maka kemiripan yang dimiliki semakin tinggi.

\section{Pengujian dengan Algoritma Jaro-Winkler}

Menyusun kode algoritma Stored Procedure sebagai berikut BEGIN

\#finestra:= search window, curString:= scanning cursor for the original string, curSub:= scanning cursor for the compared string

declare finestra, curString, curSub, maxSub, trasposizioni, prefixlen, maxPrefix int;

declare char1, char2 char(1);

declare common1, common2, old1, old2 varchar(255);

declare trovato boolean;

declare returnValue, jaro float;

set maxPrefix=6; \#from the original jaro - winkler algorithm

set common $1="$;

set common2="";

set finestra=(length(in1)+length(in2)-abs(length(in1)-length(in2)) ) DIV 4

+ ((length(in1)+length(in2)-abs(length(in1)-length(in2)))/2) $\bmod 2$;

set old $1=$ in 1 ;

set old2=in2;

\#calculating common letters vectors

set curString=1;

while curString $<=$ length(in1) and (curString $<=($ length(in2) + finestra) $)$ do

set curSub=curstring-finestra;

if $($ curSub $)<1$ then

set $\operatorname{curSub}=1$;

end if;

set maxSub=curstring+finestra;

if (maxSub)>length(in2) then

set maxSub=length(in2);

end if; 
set trovato $=$ false;

while $\operatorname{curSub}<=\operatorname{maxSub}$ and trovato $=$ false do

if substr(in1,curString, 1)=substr(in2, curSub,1) then

set common $1=$ concat $($ common $1, \operatorname{substr}($ in 1, curString, 1$)$ );

set in $2=$ concat( $($ ubstr(in2,1, curSub-1), concat("0",substr(in2, curSub+1,length(in2)-

curSub+1)));

set trovato=true;

end if;

set $\operatorname{curSub}=\mathrm{curSub}+1$;

end while;

set curString=curString+1;

end while;

\#back to the original string

set in $2=$ old 2 ;

set curString $=1$;

while curString $<=$ length(in2) and (curString $<=($ length(in1)+finestra)) do

set curSub=curstring-finestra;

if (curSub) $<1$ then

set $\operatorname{curSub}=1$;

end if;

set maxSub=curstring+finestra;

if (maxSub) >length(in1) then

set maxSub=length(in1);

end if;

set trovato $=$ false;

while $\operatorname{curSub}<=$ maxSub and trovato=false do

if substr(in2,curString, 1)=substr(in 1,curSub,1) then

set common $2=$ concat $($ common2, substr(in2,curString, 1$)$ );

set in $1=$ concat (substr(in1,1,curSub-1), concat("0",substr(in1,curSub+1,length(in1)-

curSub+1)));

set trovato=true;

end if;

set $\operatorname{curSub}=\mathrm{curSub}+1$;

end while;

set curString=curString + ;

end while;

\#back to the original string

set in $1=$ old 1 ;

\#calculating jaro metric

if length (common1)<>length(common2)

then set jaro $=0$;

elseif length $($ common 1$)=0$ or length $($ common 2$)=0$

then set jaro $=0$;

else

\#calcolo la distanza di winkler

\#passo 1: calcolo le trasposizioni

set trasposizioni $=0$;

set curString=1;

while curString $<=$ length (common1) do

if(substr(common1, curString, 1)<>substr(common2, curString, 1)) then

set trasposizioni $=$ trasposizioni +1 ; 
end if;

set curString=curString+1;

end while;

set jaro $=$

(

length(common1)/length(in1)+

length(common2)/length(in2)+

(length(common1)-trasposizioni/2)/length(common1)

)$/ 3$;

end if; \#end if for jaro metric

\#calculating common prefix for winkler metric

set prefixlen $=0$;

while (substring(in1,prefixlen+1,1)=substring $($ in 2 ,prefixlen $+1,1)$ ) and $($ prefixlen $<6)$ do set prefixlen= prefixlen +1 ;

end while;

\#calculate jaro-winkler metric

return jaro+(prefixlen*0.1*(1-jaro));

END

Pemanggilan Stored Procedure dengan Algoritma Jaro-Winkler Dalam Query

SELECT *, jaro_winkler('nama', "Thomas") + jaro_winkler('tgl_lahir', "1965-05-08") AS

score FROM warga ORDER BY score DESC LIMIT 10;

\section{Hasil Query Dengan Algoritma Jaro-Winkler}

Tabel 2 merupakan hasil query dengan parameter nama "Thomas" dan tgl_lahir "1965-05-08" ditampilkan dalam setiap sepuluh baris record hasil.

Tabel 2. Hasil Query Jaro-Winkler

\begin{tabular}{|c|c|c|c|c|c|c|}
\hline id & nama & tgl_lahir & tpt_lahir & no-ktp & alamat & skore \\
\hline 80938 & Thomas York & $1965-05-08$ & Fresno & $660-61-5290$ & $\begin{array}{l}15025 \text { North Holy See } \\
\text { (Vatican City State) Ave. }\end{array}$ & ‘1.9393937 \\
\hline 67617 & Thomas Holt & 1963-05-08 & Hollister & $628-27-0989$ & $\begin{array}{l}59106 \text { South Monrovia } \\
\text { Blvd }\end{array}$ & ' 1.8538383841 \\
\hline 81897 & Thomas Gentry & 1953-04-08 & Waterbury & $116-65-0946$ & $\begin{array}{l}75534 \text { West Northern } \\
\text { Mariana Islands Way }\end{array}$ & ‘' 1.8215384483 \\
\hline 23447 & Thomas Bright & $1956-01-20$ & Effingham & 081-96-0885 & 33624 East Reunion ST. & ‘1.78820514 \\
\hline 38763 & Thomas Odom & 1977-03-08 & St. Marys & $539-42-9043$ & 47968 Athens Ln. & ‘1.77939397 \\
\hline 45996 & Thomas Wolfe & 1951-04-07 & Bradford & $475-63-1377$ & 72008 Des Moines ST. & ‘ 1.77333337 \\
\hline 74059 & Thomas Beach & 1953-07-01 & Homer & $623-49-7497$ & 22732 Columbus Ave. & ‘1.77333337 \\
\hline 77695 & Thomas Moody & 1972-04-08 & Ansonia & 479-60-9006 & $\begin{array}{l}80279 \text { South Mauritius } \\
\text { Ave. }\end{array}$ & ‘ 1.77333337 \\
\hline 99199 & Thomas Curtis & 1986-08-04 & Jacksonville & $246-30-2472$ & $\begin{array}{l}96528 \text { Noth Cape Verde } \\
\text { Blvd }\end{array}$ & ‘1.7715384 \\
\hline 16802 & Thomas Kinney & 1982-04-08 & Oakland & $365-15-1886$ & $\begin{array}{l}82353 \text { West Guinea-bissau } \\
\text { Ln. }\end{array}$ & ‘ 1.7682051 \\
\hline
\end{tabular}


Berdasarkan tabel 2 ditemukan bahwa terdapat sejumlah nama yang mengandung "Thomas" ditempatkan pada urutan teratas demikian selanjutnya. Pada pengujian algoritma JaroWinkler semakin besar nilai skor yang dimiliki maka kemiripan yang dimiliki semakin tinggi.

Kemudian untuk memastikan dan memperkuat hasil temuan maka dilakukan pegujian kembali sebanyak 5 iterasi terhadap 5 nama dan tgl_lahir yang berbeda dan menghasilkan sejumlah temuan sebagaimana yang ada pada tabel 3 .

\section{Tabel 3. Hasil Perbandingan Waktu}

\begin{tabular}{llll}
\hline nama & tgl_lahir & Levenshtein & Jaro-Winkler \\
\hline Thomas & $1965-05-08$ & $155.7721 \mathrm{sec}$ & $116.3347 \mathrm{sec}$ \\
Robert & $1963-05-04$ & $153.3558 \mathrm{sec}$ & $76.2600 \mathrm{sec}$ \\
William & $1965-05-08$ & $164.7141 \mathrm{sec}$ & $85.8108 \mathrm{sec}$ \\
Dorothea & $1995-02-07$ & $176.8801 \mathrm{sec}$ & $89.9443 \mathrm{sec}$ \\
\hline Margareth & $1997-08-06$ & $190.9766 \mathrm{sec}$ & $99.7793 \mathrm{sec}$ \\
\hline
\end{tabular}

Pada tabel 3 dapat diamati bahwa dari lima kali pengujian pada masing-masing algoritma ditemukan hasil capaian waktu yang berbeda untuk lima parameter berbeda. Algoritma JariWinkler memperoleh waktu lebih cepat dibandingkan dengan algoritma Levenshtein Distance.

\section{Simpulan dan Saran}

\section{Simpulan}

Dari hasil pengamatan selama melakukan pengujian dapat diambil kesimpulan sebagai berikut :

1. Pada algoritma Levenshtein Distance semakin kecil nilai skor yang dimiliki maka kemiripan semakin tinggi.

2. Pada algoritma Jaro-Winkler semakin besar nilai skor yang dimiliki maka kemiripan semakin tinggi.

3. Algoritma Jaro-Winkler memiliki kompleksitas waktu quadratic runtime complexity yang sangat efektif pada string pendek dan dapat memperoleh hasil lebih cepat dari algoritma Levenshtein Distance.

4. MetodeJaro-Winklermudah untuk diimplementasikan dan efektif dalam hasil yang dicapai.

5. Penelitian yang dilakukan dapat digunakan sebagai dasar menentukan penggunaan metode pencarian data untuk beberapa jenis kegiatan lainnya yang serupa.

\section{Saran}

Hasil penelitian dapat digunakan sebagai dasar menentukan pemilihan algoritma pencarian terbaik. Diharapkan adanya penelitian lanjutan untuk mengembangkan hasil sehingga algoritma Jaro-Winkler dapat diimplementasikan pada objek yang berbeda. 


\section{Daftar Pustaka}

Dita, R.P. (2015). Implementasi Algoritma Levenshtein Distance Untuk Search Suggestion Pada Aplikasi Pengelolaan Infformasi Kerusakan Mobil (D-TAB). Jurnal Ilmiah Universitas Bakrie, 3 (3).

DuBois, P.(2014). MySQLCookBook. (3rd Edition). Publisher : O'REILLY

Dwitiyastuti,R.N, Muttaqin, A dan Aswin,M.(2013).Pengoreksi Kesalahan Ejaan Bahasa Indonesia Menggunakan Metode Levenshtein Distance.Malang: Universitas Brawijya.1(2)

http://www.informit.com/articles/article.aspx?p=29661

http://www.sqlservercentral.com/articles/Fuzzy+Match/65702/

Kurniawati, A. Puspitodjati, S, Rahman,S.(2014).Implementasi Algoritma Jaro-Winkler Distance untuk Membandingkan Kesamaan Dokumen Berbahasa Indonesia.Depok: Universitas Gunadarma.

Oktamal, F. Saptono, R dan Sulistyo, M.E.(2015) Jaro-Winkler Distance dan Steaming untuk Deteksi Dini Hama Dan Penyakit Padi. Seminar Nasional Sistem Informasi Indonesia (SESINDO),Departemen Sistem Informasi Institut Teknologi Sepuluh November.

Sugiyono.(2009).Metode Penelitian Kuantitatif Kualitatif dan R\&D.Bandung : Alfabeta 